\title{
Retraction Note to: Effect of the Support on the Mechanism of Partial Oxidation of Methane on Platinum Catalysts
}

\author{
Fabio B. Passos ${ }^{1}$ - Elaine R. Oliveira ${ }^{1} \cdot$ Lisiane V. Mattos $^{2} \cdot$ Fabio B. Noronhe ${ }^{2}$
}

Published online: 31 July 2020

○) Springer Science+Business Media, LLC, part of Springer Nature 2020

\section{Retraction to: \\ Catalysis Letters (2006) 110(3-4):261-267 https://doi.org/10.1007/s10562-006-0119-6}

The Publisher has retracted this article by Passos et al. [1]. Owing to a technical error Passos et al. (2006) [2] was republished in the same journal creating a duplicate publication [1]. The Publisher apologises to the authors and to readers for this error. All authors agree with this retraction.

\section{References}

1. Passos FB, Oliveira ER, Mattos LV, Noronhe FB (2006) Cat Lett 110:261-267

2. Passos FB, Oliveira ER, Mattos LV, Noronha FB (2006) Cat Lett 110:161-167

Publisher's Note Springer Nature remains neutral with regard to jurisdictional claims in published maps and institutional affiliations.

The original article can be found online at https://doi.org/10.1007/ s10562-006-0119-6.

Fabio B. Passos

fbpassos@vm.uff.br

1 Universidade Federal Fluminense, Rua Passo da Pátria, 156, Niterói, RJ CEP 24210-240, Brazil

2 Instituto Nacional de Tecnologia, Av. Venezuela, 82, Rio de Janeiro, RJ CEP 20081-312, Brazil 